\title{
REVISTA PAUSA NA REDE : EXPRESSÕES ARTÍSTICAS EM TEMPOS DE QUARENTENA
}

Amanda M. P. Leite

André Demarchi

Renata Ferreira da Silva

Ricardo Ribeiro Malveira

Suiá Omim

Clique na imagem para ter acesso ao arquivo PDF:

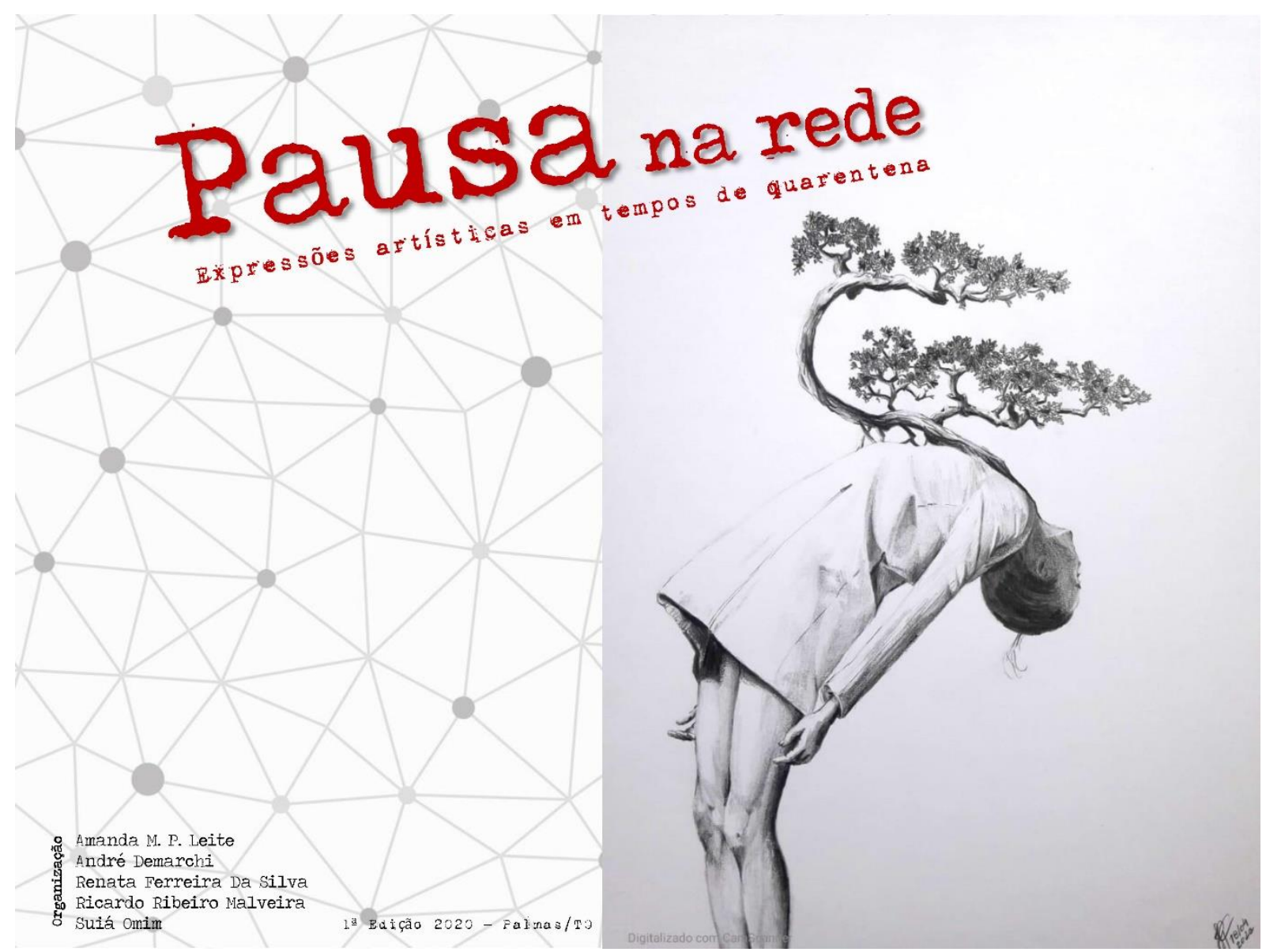

